Gut, 1972, 13, 947-957

\title{
Five cases of alpha chain disease
}

\author{
WILLIAM F. DOE, K. HENRY, J. R. HOBBS ${ }^{1}$, F. AVERY JONES, C. E. DENT, \\ AND C. C. BOOTH \\ From the Departments of Medicine and Pathology, Royal Postgraduate Medical School, Central Middlesex \\ Hospital, and University College Hospital, London
}

SUMMARY Five patients suffering from alpha chain disease are described. Clinically the patients presented with clubbing and the symptoms of malabsorption. There was a characteristic, predominantly plasma cell infiltrate of the wall of the small intestine. Spread of the plasmacytosis beyond the small intestine to bone marrow (1), peripheral blood (1), and probably the nasopharyngeal lymphoid tissue (1) is described. Fragments of the heavy chain of $\operatorname{IgA}$ (alpha chain) were found in serum (5), urine (3), jejunal fluid (2), and saliva (1). The jejunal biopsy of one patient was shown to synthesize free alpha chain in tissue culture. A new and simple immunoselection technique for the identification of free alpha chain is described. Marked clinical remissions were achieved in two patients treated with intermittent cytotoxic and steroid therapy, and in a third patient who received intermittent cytotoxic therapy and tetracycline.

There is a basic structure common to all immunoglobulin molecules. This comprises a pair of heavy polypeptide chains which characterize each immunoglobulin class ( $\gamma$ for IgG, $\alpha$ for IgA, and $\mu$ for IgM), and a pair of light chains $(\mathrm{K}$ or $\mathrm{L})$ which is common to all immunoglobulin classes. Reductive cleavage of the immunoglobulin molecule by papain yields two Fab fragments each consisting of a light chain and part of a heavy chain, and an Fc fragment comprising the portions of the two heavy chains which carry the specific determinants characterizing each immunoglobulin class.

In many lymphoid-plasmocytic disorders such as multiple myeloma, abnormal plasma cells produce an excess of a specific immunoglobulin class with free light chains or an excess of free light chains alone. In 1964, a new syndrome was described in which abnormal plasma cells produced an anomalous polypeptide fragment, consisting of the $\mathrm{Fc}$ fragment of IgG (Franklin, Lowenstein, Bigelow, and Meltzer, 1964). This condition was named 'heavy chain disease'. Similar disorders of immunoglobulin peptide synthesis and assembly have been described for IgA, the condition of 'alpha chain disease' (Rambaud, Bognel, Prost, Bernier, Le Quintrec, Lambling, Danon, Hurez, and Seligmann, 1968) and IgM, 'mu chain disease' (Ballard, Hamilton, Marcus, and Illes, 1970). Subsequent case

${ }^{1}$ Present address: Department of Chemical Pathology, Westminster Hospital, London.

Received for publication 16 October 1972. reports of alpha chain disease (Doe, Hobbs, Henry, and Dowling, 1970; Laroche, Seligmann, Merillon, Turpin, Marche, Cerf, Lemaigre, Forest, and Hurez, 1970; Rogé, Druet, and Marche, 1970; Irunberry, Benallegue, Illoul, Timsit, Abbadi, Benabdallah, Boucekkine, Ould-Aoudia, and Colonna, 1970; Zlotnick and Levy, 1971) have described a strikingly uniform clinico-pathological picture.

The purpose of this paper is to describe five patients suffering from alpha chain disease presenting several new features. A simple new diagnostic method for detecting the alpha heavy chain fragment and the clinical course and response to cytotoxic therapy in three of these patients will be described.

\section{Materials and Methods}

\section{BIOPSIES}

Peroral jejunal biopsies were taken from beyond the ligament of Treitz using a Crosby capsule. Biopsy tissue was processed and stained for light and electron microscopy using standard techniques.

\section{PROTEIN STUDIES}

Electrophoresis was carried out on cellulose acetate and immunoelectrophoresis by the high-voltage method of Wieme (1965). The immunoselection plate method of Rádl (1970) was adapted to detect the presence of free alpha chain in serum. Serum was electrophoresed in agar gel containing antisera to both $\mathrm{K}$ and $\mathrm{L}$ light chains. Thus all serum proteins 
containing light chains precipitated close to the origin, while alpha chain fragments were free to migrate. Free alpha chain was then detected using rabbit antiserum against polyclonal human IgA. A specific rabbit antihuman secretory piece antiserum was provided by Dr R. Thompson and a specific anti-lactoferrin antiserum by Professor $\mathbf{J}$. Heremans.

Albumin and immunoglobulin levels were measured by a radial immunodiffusion method (Hobbs, 1970) using the standards and normal ranges specified. In addition the sera of the five patients were tested in serial dilutions against pooled normal serum and a standard of purified polyclonal IgA.

Parotid secretion was collected by Curby cup, without stimulation and jejunal fluid was obtained at jejunal biopsy. A solution of equal parts of Trasylol and $10 \%$ epsilon-amino-caproic acid was used to inhibit proteinases. Urine, saliva, jejunal fluid, and tissue culture fluid were concentrated where necessary by ultrafiltration in collodion thimbles (Sartorius) which retained substances with mol wt greater than 5000 .

\section{TISSUE CULTURE}

Fresh jejunal mucosa was incubated at $37^{\circ} \mathrm{C}$ in $0.25 \%$ trypsin in phosphate-buffered saline free of calcium and magnesium (Dulbecco A Oxoid). Ten per cent foetal calf serum in TC 119 medium free of L-leucine and DL- lysine (Tissue Culture Services) containing $20 \mu \mathrm{Ci}$ of tritiated L-leucine and DLlysine (Radiochemical Centre, Amersham) was then added to the spun cellular deposit and incubated at $37^{\circ} \mathrm{C}$ in the presence of $5 \% \mathrm{CO}_{2}$ in air. Following freezing, thawing, and probe sonication, the supernatant fluid was tested for the presence of alpha chain material by immunoelectrophoresis and autoradiography using the method of Doniach and Pelc (1950).

\section{IMMUNOFLUORESCENT STUDIES}

Cryostat sections of fresh frozen jejunal mucosa were stained with specific antisera for IgA, IgG, and IgM conjugated with fluoroscein isothiocyanate (FITC) (Nordic Laboratories) and anti-K and
anti-L anti-light chain antisera conjugated with rhodamine, using the direct staining technique. Fluorescence was viewed through a Leitz orthoplan microscope.

\section{Clinical Features}

The predominant clinical features of the five patients are summarized in Table I. The ages of the patients at the time of presentation ranged from 17 to 36 years and there were four males and one female. Two of the patients were Pakistanis, recently arrived in England, while the remaining three, a Greek, a Libyan and a Persian, were investigated following their referral to London for medical treatment.

\section{SYMPTOMS}

Weight loss and diarrhoea suggesting steatorrhoea were presenting symptoms in all five patients. In addition three patients complained of intermittent generalized abdominal pain (cases 3, 4, and 5), and tetany developed on several occasions in one other (case 2). In one patient (case 3) blood appeared in the saliva; peripheral oedema was a presenting symptom in case 4 . The duration of these symptoms ranged from seven months (case 5) to three and a half years (case 4 ).

\section{INTERCURRENT DISEASE}

One patient (case 2) developed a groin abscess from which human tubercle bacilli were cultured. His tuberculosis responded to chemotherapy with streptomycin, PAS, and isoniazid. A gastric ulcer was found in case 4 while he was receiving prednisone therapy in Greece.

\section{FAMILY HISTORY}

There was no family history of gastrointestinal disease in relatives of any of the five patients.

\section{PHYSICAL SIGNS}

Finger clubbing and signs of weight loss were marked in four patients (cases 1, 2, 3, and 4) and in addition peripheral oedema occurred in case 4 . A nasopharyngeal lymphoid tissue tumour was found

\begin{tabular}{|c|c|c|c|c|c|c|c|}
\hline \multicolumn{2}{|c|}{ Case } & \multirow{2}{*}{$\begin{array}{l}\text { Age } \\
17 \\
29 \\
30\end{array}$} & \multirow{2}{*}{$\begin{array}{l}\text { Sex } \\
\mathbf{F} \\
\mathbf{M} \\
\mathbf{M}\end{array}$} & \multirow{2}{*}{$\begin{array}{l}\text { Nationality } \\
\text { Libyan } \\
\text { Pakistani } \\
\text { Pakistani }\end{array}$} & \multirow{2}{*}{$\begin{array}{l}\text { Duration of } \\
\text { Symptoms } \\
3 \mathrm{yr} \\
1 \frac{\mathrm{yr}}{2 \mathrm{yr}}\end{array}$} & \multirow{2}{*}{$\begin{array}{l}\text { Symptoms } \\
\text { Weight loss, diarrhoea } \\
\text { Weight loss, diarrhoea, tetany } \\
\text { Weight loss, abdominal pain, diarrhoea, } \\
\text { bright blood in saliva }\end{array}$} & \multirow{2}{*}{$\begin{array}{l}\text { Signs } \\
\text { Wasting, finger clubbing } \\
\text { Wasting, finger clubbing } \\
\text { Wasting. finger clubbing, nasopharyngeal } \\
\text { lymphoid tissue tumour }\end{array}$} \\
\hline $\begin{array}{l}1 \\
2 \\
3\end{array}$ & $\begin{array}{l}\text { FT } \\
\text { AH } \\
\text { LM }\end{array}$ & & & & & & \\
\hline 4 & GS & 33 & $\mathbf{M}$ & Greek & $3 \frac{1}{2} \mathrm{yr}$ & $\begin{array}{l}\text { Weight loss, abdominal pain, diarrhoea, } \\
\text { oedema }\end{array}$ & $\begin{array}{l}\text { Wasting, finger clubbing, peripheral } \\
\text { oedema }\end{array}$ \\
\hline
\end{tabular}

Table I Clinical features in five cases of alpha chain disease 


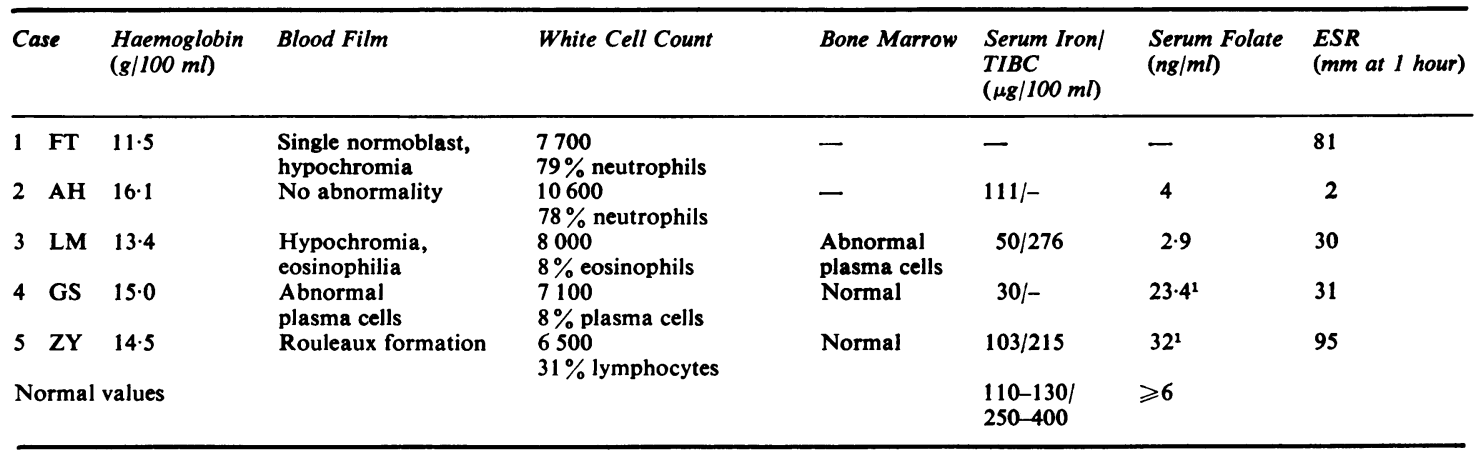

Table II Haematological findings at the time of presentation

${ }^{1}$ Receiving folic acid therapy.

$-=$ not done.

TIBC $=$ total iron-binding capacity.

in case 3 but none of the five patients had lymph node, liver, or spleen enlargement, nor was any abdominal mass palpable.

\section{Investigations}

\section{HAEMATOLOGICAL FINDINGS}

The results of haematological studies are shown in Table II. Eosinophilia was present in case 3 and morphologically abnormal plasma cells with a large nucleus, prominent nucieolus, and absence of peripheral chromatin clumping were found in the peripheral blood in case 4 . Bone marrow examination was normal in cases 4 and 5 . Normal numbers of plasma cells were seen in the bone marrow in case 3 but many primitive plasma cells and a number of 'flame cells' were seen.

\section{BIOCHEMISTR Y}

The biochemical findings are shown in Table III. Hypocalcaemia and hypomagnesaemia were present in cases 1,2 , and 4 . A striking increase in serum alkaline phosphatase was found in four patients, ranging from 23 to $74 \mathrm{KAU}$. In cases 1,2 , and 3 this

\begin{tabular}{|c|c|c|c|c|}
\hline Case & $\begin{array}{l}\text { Calcium } \\
(m N)\end{array}$ & $\begin{array}{l}\text { Inorganic } \\
\text { Phosphorus } \\
(m N)\end{array}$ & $\begin{array}{l}\text { Magnesium } \\
(m N)\end{array}$ & $\begin{array}{l}\text { Total Serum } \\
\text { Alkaline Phosphatase } \\
(K A U)\end{array}$ \\
\hline $\begin{array}{ll}1 & \mathrm{FT} \\
2 & \mathrm{AH} \\
3 & \mathrm{LM} \\
4 & \mathrm{GS} \\
5 & \mathrm{ZY} \\
\text { Normal } \\
\text { values }\end{array}$ & $\begin{array}{l}3 \cdot 6 \\
3 \cdot 2 \\
5 \cdot 1 \\
4 \cdot 4 \\
4 \cdot 7 \\
4 \cdot 5-5 \cdot 5\end{array}$ & $\begin{array}{l}\overrightarrow{2 \cdot 1} \\
2 \cdot 4 \\
1 \cdot 6 \\
2 \cdot 2 \\
1 \cdot 5-2.5\end{array}$ & $\begin{array}{l}0.5 \\
0.6 \\
1.5 \\
i \cdot 0 \\
2 \cdot 2 \\
1 \cdot 4-1 \cdot 8\end{array}$ & $\begin{array}{r}23 \\
74 \\
35 \\
28 \\
5 \\
\\
3-13\end{array}$ \\
\hline
\end{tabular}

Table III Serum biochemical studies

$-=$ not done. increase was shown to be largely caused by a massive increase in the intestinal isoenzyme of alkaline phosphatase (Doe, Thomas, and Moss, 1972).

\section{GASTROINTESTINAL STUDIES}

\section{Absorption tests}

Malabsorption of fat was found in all five cases, and in cases 3, 4 and 5, D xylose and vitamin $\mathrm{B}_{12}$ malabsorption was demonstrated as well (Table IV).

\begin{tabular}{|c|c|c|c|}
\hline Case & $\begin{array}{l}\text { Faecal Fat } \\
(\mathrm{g} / 24 \mathrm{hr})\end{array}$ & $\begin{array}{l}\text { DXylose } \\
(g / 5 \mathrm{hr})\end{array}$ & $\begin{array}{l}\text { Schilling Test }(\%) \\
\left(B_{12} \text { dose }+ \text { Intrinsic Factor }\right)\end{array}$ \\
\hline \multirow{6}{*}{$\begin{array}{ll}1 & \text { FT } \\
2 & \text { AH } \\
3 & \text { LM } \\
4 & \text { GS } \\
5 & \text { ZY } \\
\text { Normal } \\
\text { values }\end{array}$} & 7 & - & - \\
\hline & 30 & - & - \\
\hline & 10.9 & $2 \cdot 3$ & 4.5 \\
\hline & 21.4 & 2.5 & 0.99 \\
\hline & $6 \cdot 4$ & $2 \cdot 6$ & 5.7 \\
\hline & 5 & 5 & $>10$ \\
\hline
\end{tabular}

Table IV Results of absorption tests

$-=$ not done.

\section{Stool examination}

Stool examination revealed Trichuris trichuria and hookworm in case 3 when initially seen and Giardia lamblia were found in case 4 before referral to London.

\section{Radiology}

Barium follow-through examination revealed segments of small bowel dilatation, flocculation, and coarse mucosal folds in the four cases examined $(2,3,4$, and 5$)$, and in cases 3 and 5 a diffuse nodular appearance was seen (Fig. 1). In addition, narrowing of a short segment of small intestine was demonstrated in case 4. 


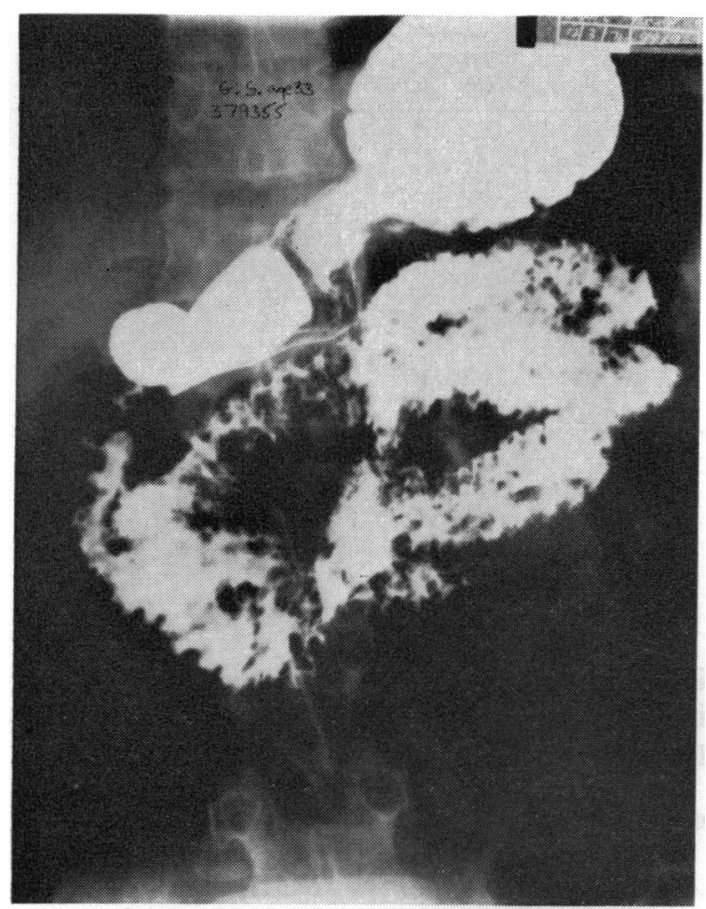

Fig. 1 Barium follow-through examination showing the hypertrophied mucosal folds with a diffuse nodular appearance (case 4).

\section{HISTOLOGY}

Light microscopy

The jejunal mucosa in all the biopsy specimens studied was abnormal and presented a most distinctive appearance. The basic abnormality was a massive infiltrate of the lamina propria with mononuclear cells resulting in a thickened mucosa with distortion of normal villous architecture (Fig. 2) but the luminal epithelium showed a relatively normal appearance. The cellular infiltrate was predominantly plasma cell in type but showed some individual variation. In case 3 the majority of cells were immature plasma cells with only occasional lymphocytes (Fig. 3). In cases 1, 2, and 5 there were more numerous lymphocytes and the plasma cells appeared more mature, while in case 4 there was a larger proportion of cells intermediate between lymphocytes and plasma cells. Eosinophils were prominent in case 2. A feature present only in the jejunal biopsy of case 5 was a remarkable infiltrate of the luminal epithelium with mature lymphocytes. Infiltration into the submucosa with plasma cells and lymphocytes could only be established with certainty in case 1 .

The rectal biopsies in cases 3 and 4 showed an increase of mature plasma cells in an otherwise normal mucosa. The liver biopsies from cases 2, 3, and 4 and the bronchial biopsy from case 3 were normal. The nasopharyngeal lymphoid tissue from case 3 showed an increase in /mature plasma cells with formation of Russell bodies and prominent lymphoid follicles. No evidence of amyloid deposition was seen in any of these sections.

\section{Electron microscopy}

The vast majority of cells in case 3 showed the cytoplasmic and nuclear structure of plasma cells (Fig. 4). Most were rounded with round to oval,

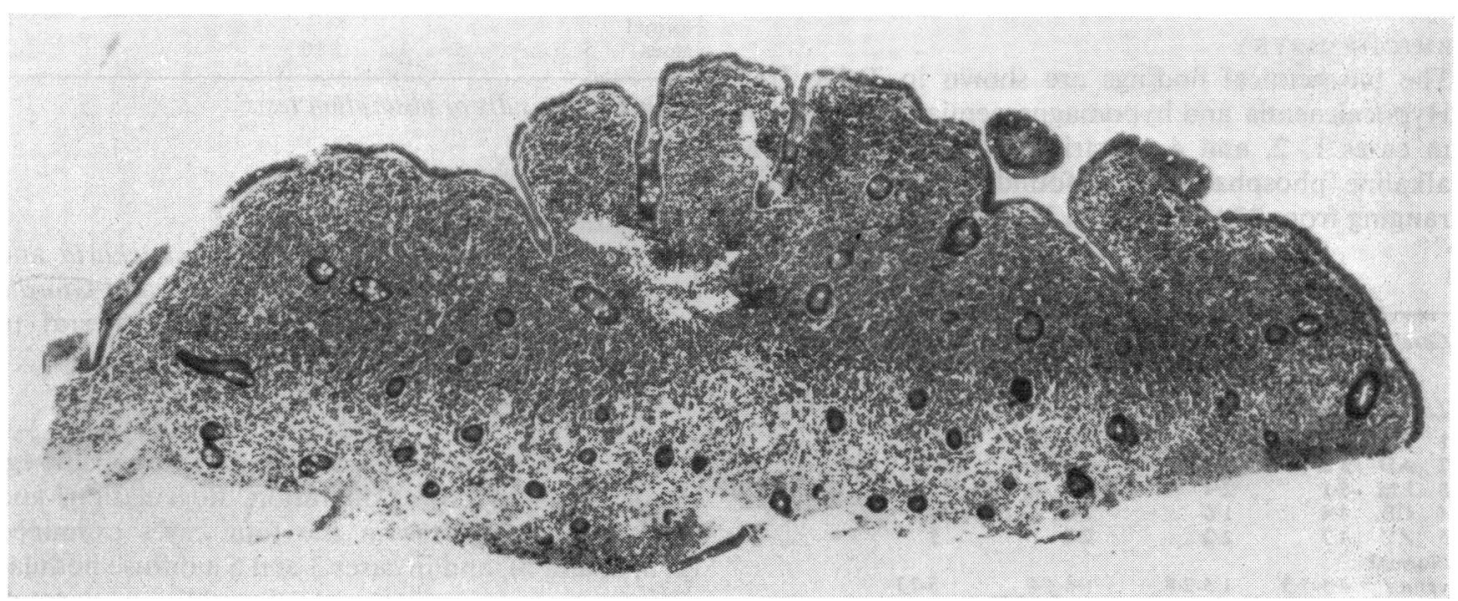

Fig. 2 Jejunal biopsy (case 3) showing flat deformed villi, sparse crypts, preservation of luminal epithelium, and a massive cellular infiltrate $(\times 60)$. 


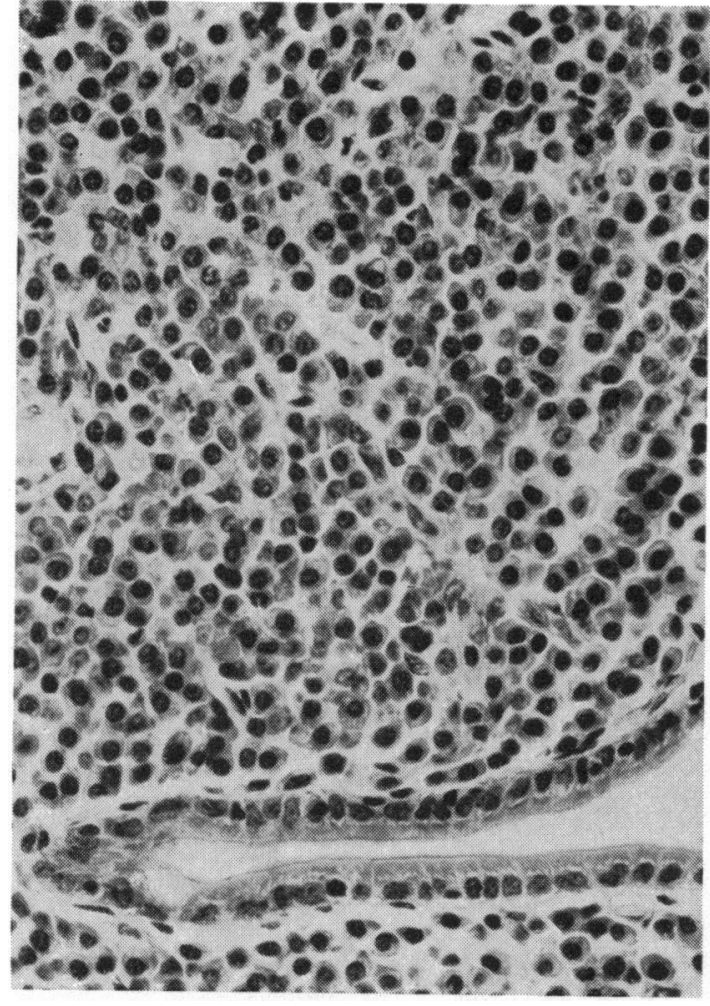

Fig. 3 The cellular infiltrate (case 3 ) is composed largely of immature plasma cells $(\times 360)$.

regularly contoured nuclei. Nucleoli were prominent and numerous, and nuclear bodies were frequently seen. Except in the most immature form, the rough endoplasmic reticulum was highly developed and showed distension of the cisternae with moderately electron-dense granular material. The Golgi apparatus, when visualized, was prominent. The infiltrate in the jejunal lamina propria of case 5 was composed of apparently mature, actively secreting plasma cells together with a few lymphocytes.

The appearances of the cellular infiltrate in case 4 differed quite markedly at EM level from those of cases 3 and 5 , in that, although plasma cells and lymphocytes were present, the majority of cells showed the cytoplasmic configuration of actively secreting plasma cells with widely distended endoplasmic reticulum, but possessed nuclei of lymphocytic type as shown by their chromatin content and arrangement, and the very much more irregular nuclear outline (Fig. 5). Thus the majority of cells were intermediate between plasma cells and lymphocytes.

\section{PROTEIN STUDIES}

The results of protein investigations are shown in Table V. Electrophoresis revealed humps of abnormal protein of alpha $_{2}$ to fast gamma mobilities in the sera of cases 1, 2, 3 and 5 (Fig. 6). In case 4, however, the presence of this protein was identified only by immunoelectrophoresis. In addition all five patients' sera showed reduced gamma globulins of slow mobility. Jejunal fluid from case 3 (Fig. 6) and the tissue culture fluid in which his jejunal biopsy was maintained showed a narrow band in the beta position. When cut out and tested against specific antisera, this band contained only alpha chain. No reaction occurred with antilactoferrin, antisecretory piece or antilight chain ( $\mathrm{K}$ and $\mathrm{L}$ ) antisera indicating the monoclonal nature of this protein isolated directly from the gut lumen and from tissue culture of jejunal mucosa.

Immunoselection plates readily detected free alpha chain in all five patients' sera (Fig. 7), in jejunal fluid of cases 3 and 4 and in the urine of cases 3,4 , and 5 . Free alpha chain was detected in the saliva of case 4 but none was found in the jejunal fluid of case 5 or the saliva of cases 3 and 5 (Table V).

Following thin-layer chromatography of sera in Sephadex G200, immunodiffusion was used to detect alpha chain arcs. These developed mainly opposite the $2 \%$ blue dextran marker (19S or greater) in all five sera, indicating that the alpha chain was present in a polymerized form.

The alpha chain protein from all five patients

\begin{tabular}{|c|c|c|c|c|c|c|c|}
\hline \multirow[t]{2}{*}{ Case } & \multirow[t]{2}{*}{ Serum Albumin $(\mathrm{g} / 100 \mathrm{ml})$} & \multicolumn{2}{|c|}{ Serum Immunoglobulins $(\mathrm{mg} / 100 \mathrm{ml})$} & \multicolumn{4}{|c|}{ Distribution of Free Alpha Chain } \\
\hline & & $\operatorname{Ig} G$ & $\operatorname{Ig} M$ & Serum & Urine $\times 300$ & Jejunal Fluid $\times 7$ & Saliva $\times 7$ \\
\hline $\begin{array}{ll}1 & \text { FT } \\
2 & \text { AH } \\
3 & \text { LM } \\
4 & \text { GS } \\
5 & \text { ZY } \\
\text { Normal }\end{array}$ & $\begin{array}{l}1 \cdot 7 \\
3.9 \\
2 \cdot 4 \\
2.7 \\
2.9 \\
3 \cdot 5-5.5\end{array}$ & $\begin{array}{l}135 \\
860 \\
620 \\
300 \\
560 \\
510-1700\end{array}$ & $\begin{array}{l}10 \\
14 \\
24 \\
10 \\
80 \\
47-170\end{array}$ & $\begin{array}{l}++++ \\
++ \\
++++ \\
++ \\
+++\end{array}$ & $\begin{array}{l}- \\
\overline{+} \\
+ \\
+\end{array}$ & $\begin{array}{l}- \\
\overline{+} \\
++ \\
+ \\
\text { Nil }\end{array}$ & $\begin{array}{l}- \\
\overline{-} \\
\text { Nil } \\
+ \\
\text { Nil }\end{array}$ \\
\hline
\end{tabular}

Table V Protein studies

- = not done 


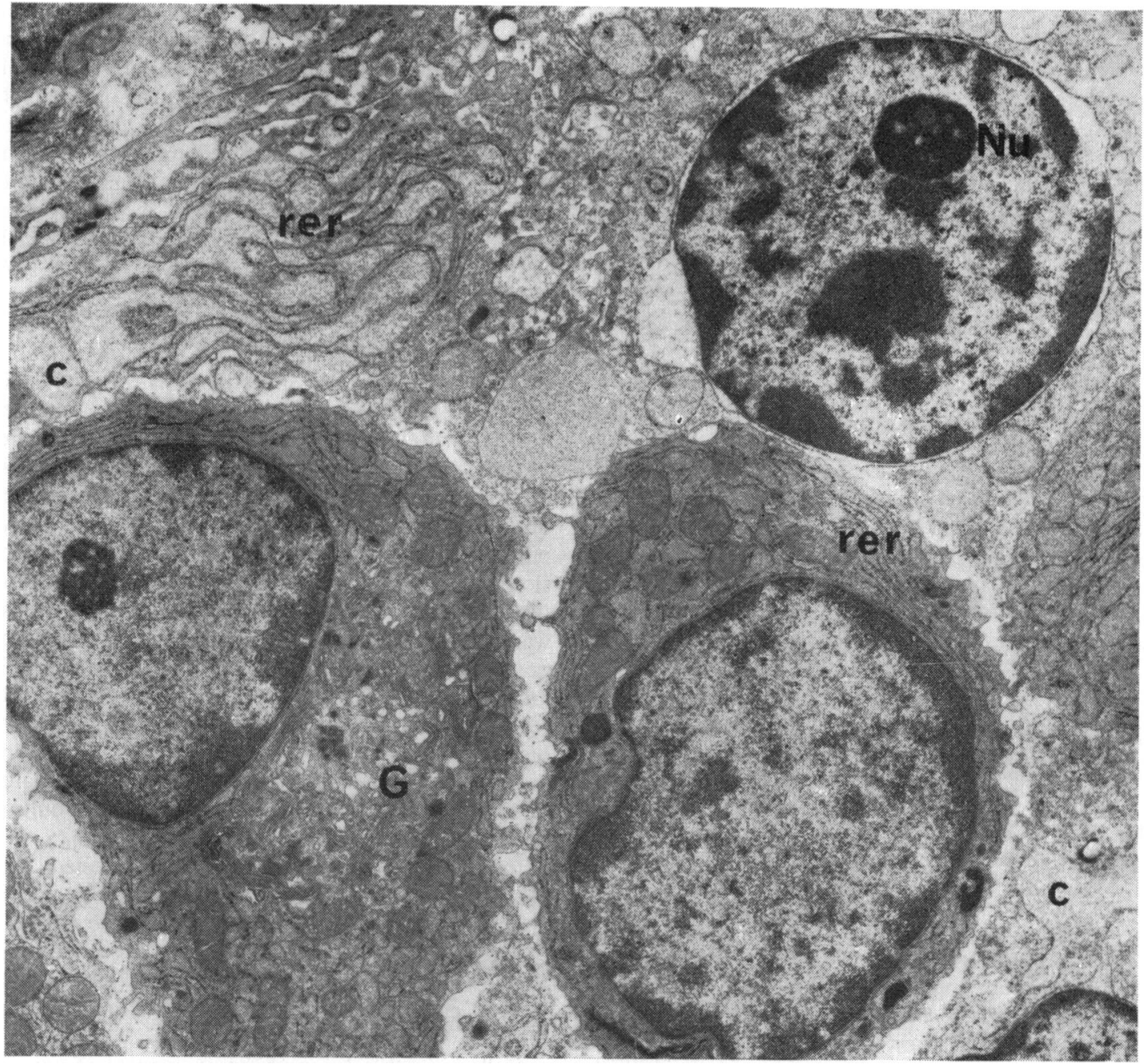

Fig. 4 The majority of the proliferating cells are immature plasma cells as shown in this electron-micrograph (case 3). The Golgi zones (G) are prominent, there is an extensive rough endoplasmic reticulum (rer). The cysternae (c) are distended with granular material. $\mathrm{Nu}$ Nucleolus $(\times 10420)$.

showed a reaction of identity with alpha chain protein of known subclass alpha ${ }_{1}$. All, therefore, belonged to the alpha $a_{1}$ subclass.

Following incubation of the jejunal biopsy from case 3 in a tissue culture containing tritiated leucine and tritiated lysine, immunoelectrophoresis and autoradiography were carried out on concentrated tissue culture material. The alpha chain arc, which was detected using a specific anti-alpha chain antiserum absorbed with an IgA-deficient saliva, was heavily labelled confirming that free alpha chain protein had been synthesised during the period of culture.
Using standard radial immunodiffusion, normal serum and polyclonal IgA standard behave with identical parallelism when the log of concentrations is plotted against the diameters of precipitin rings. Serum containing free alpha chain protein when similarly plotted lay on a different slope and could not therefore be measured against normal standards.

Immunofluorescent studies were performed on nasopharyngeal, jejunal, rectal, liver, and bronchial biopsies in case 3 and on jejunal and rectal biopsies in case 4. Normally staining plasma cells of IgA, IgM, and IgG class were present in the rectal biopsies of both patients and in the bronchial and 


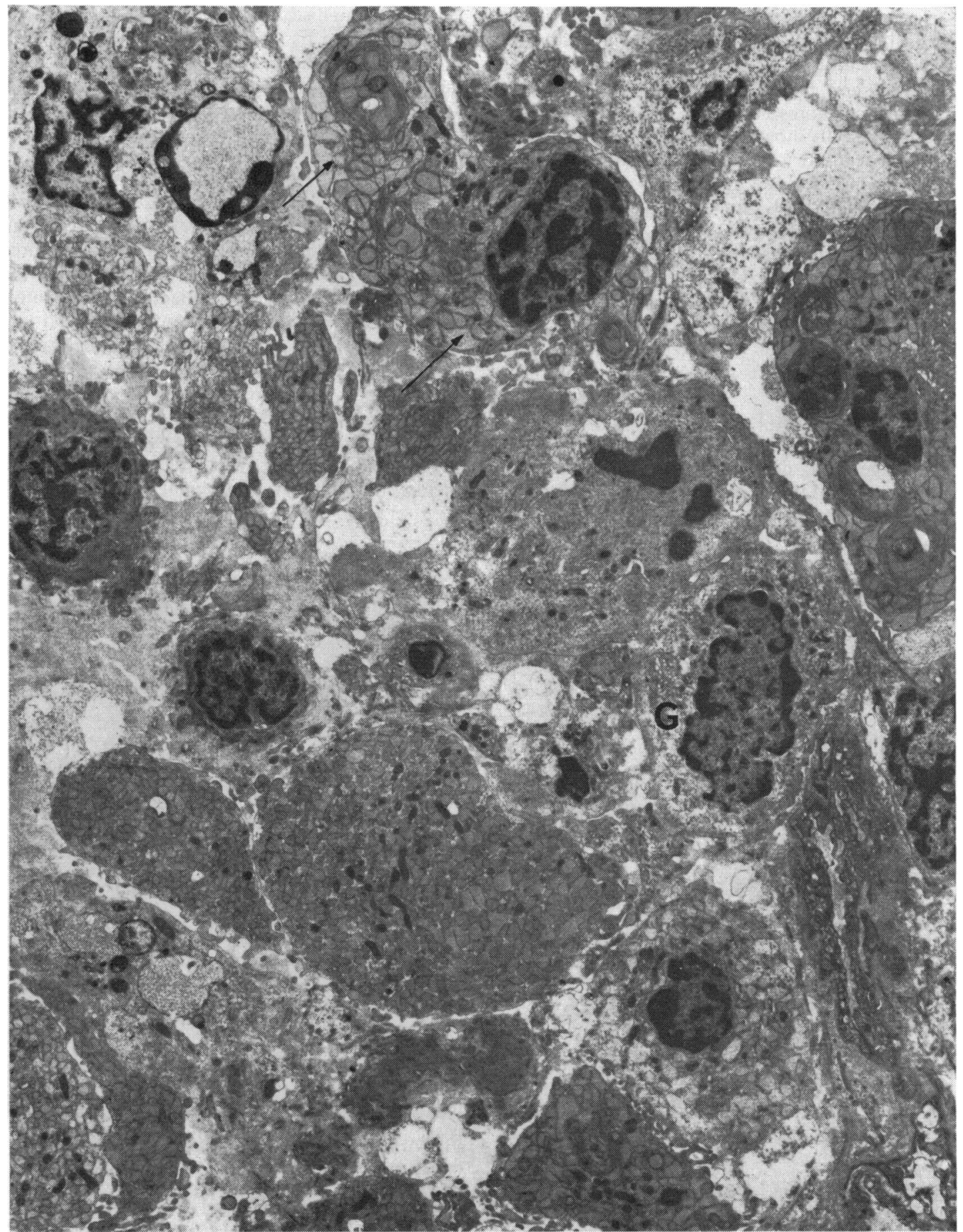

Fig. 5 Cells (case 4) showing plasmacytoid cytoplasmic features with extensive rough endoplasmic reticulum filled with granular material (arrow). The nuclei, however, resemble those of lymphocytes. $(\mathrm{G})$ Golgi $(\times 3840)$. 
liver biopsies from case 3. After staining jejunal mucosal sections from cases 3 and 4 with conjugated antiserum to IgA, relatively few plasma cells fluoresced and there was a wide variation in the brightness of fluorescence from cell to cell. IgM and IgG plasma cells showed a uniform fluorescence but appeared reduced in numbers. After quenching the section stained for IgA to remove all fluorescence, the IgA plasma cells failed to fluoresce when restained with conjugated antisera to $K$ and $L$ light chains, confirming that these plasma cells contained alpha chain devoid of light chains. A similar variation in IgA plasma cell fluorescence was also seen in nasopharangeal tissue from case 3 .

\section{Response to Treatment}

Two patients (cases 1 and 2) died as a result of intractable malabsorption in 1967, 12 months before the first description of this disease by Rambaud et al (1968). In both cases the diagnosis

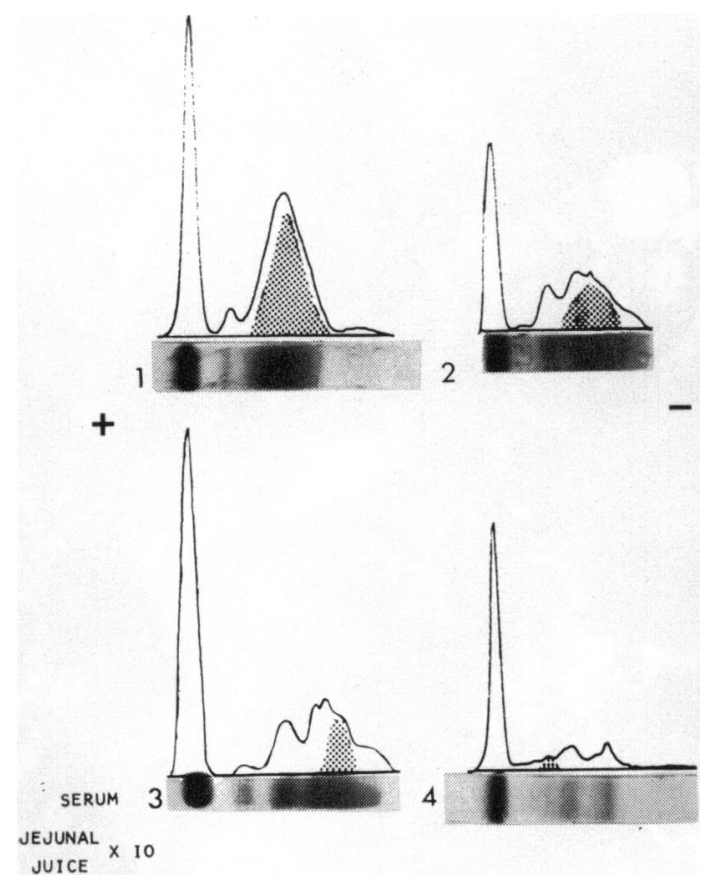

Fig. 6 Cellulose acetate electrophoresis of sera from cases 1, 2, 3, and 4. Note reduction of slow $\gamma$-globulin levels in the sera of all four patients. The $\alpha$-chain regions are indicated by dotted areas and are readily obvious as a diffuse $\beta-\gamma$ hump in patients 1,2 , and 3 . In patient 3 freshly run jejunal juice reveals a dominant narrow band in the $\beta_{2}$ position, proven to be due to free $\alpha$-chain. of alpha chain disease was made retrospectively from stored sera and tissue sections.

Cases 3, 4, and 5 were treated with long-term intermittent cytotoxic therapy. In case 3, Melphalan, $10 \mathrm{mg}$ daily for one week every six weeks, was commenced in December 1969. Two months later, the weight had increased by $2 \mathrm{~kg}$, diarrhoea had ceased, and abdominal pain was diminished. There was a progressive rise in serum albumin from 2.4 to 3.8 $\mathrm{g} / 100 \mathrm{ml}$, IgG from 620 to $1100 \mathrm{mg} / 100 \mathrm{ml}$, and IgM from 24 to $41 \mathrm{mg} / 100 \mathrm{ml}$. Electrophoresis revealed a decrease in the abnormal alpha chain band. In May 1970, the patient ceased cytotoxic therapy and the diarrhoea and abdominal pain recurred. Investigation revealed an increase in faecal fat excretion (11.5 g/24 hours) and in the serum alpha $a_{2}$-beta protein band. Jejunal biopsy appearances were unchanged, except for an increase in the number of mast cells. Melphalan therapy was begun again, together with intermittent prednisone therapy $(40 \mathrm{mg} /$ day $)$. His weight increased by $4 \mathrm{~kg}$

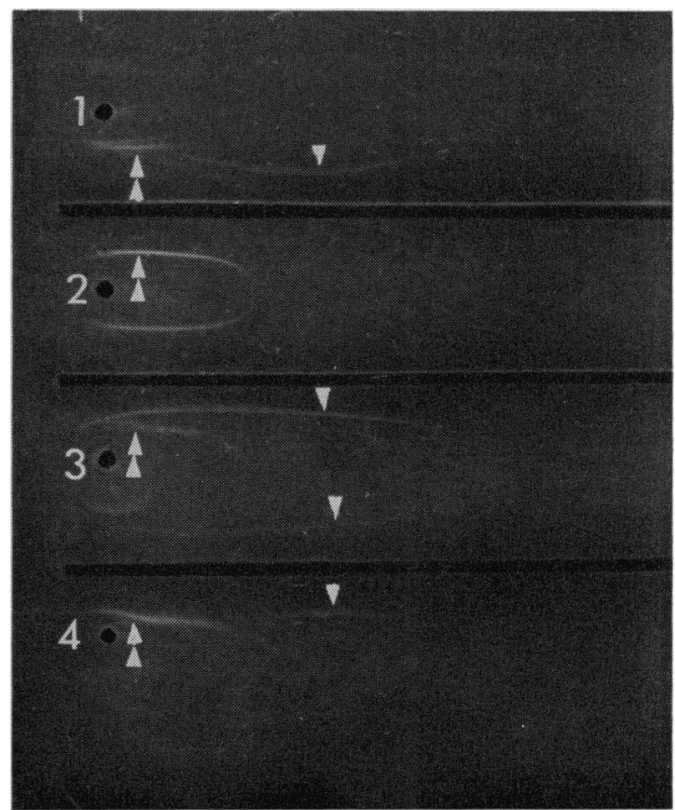

Fig. 7 Immunoselection plates for free $\alpha$-chain. $1=$ case 5, 2 = normal serum, $3=$ case $3,4=$ case 4 . Samples have been electrophoresced in agar containing ant $i-k$ and anti-l resulting in the cathodal precipitin arcs of all immunoglobulins containing light chains, indicated by double triangles. Anti- $\alpha$ in the troughs then only develops against free $\alpha$-chains, indicated by single triangles, which all show characteristic anodal mobility in agar. 
over the next three months and diarrhoea ceased. There was a progressive diminution in the abnormal alpha $_{2}$-beta band (Fig. 8). At this time jejunal biopsies showed more mature plasma cells. At present the patient is symptom-free and maintains his normal weight.

In case 4, who was initially unable to tolerate oral cytotoxic therapy, parenteral cyclophosphamide (100-200 mg daily) was given, together with a fiveday course of oral prednisone therapy (60 mg daily). A month later his weight began to increase, diarrhoea improved, and the abdominal pains ceased. Faecal fat excretion improved from $21.4 \mathrm{~g} / 24$ hours to $13.2 \mathrm{~g} / 24$ hours. After three months' therapy, the patient remains well.

In case 5 symptoms remitted following intermittent Melphalan, together with tetracycline therapy $500 \mathrm{mg}$ twice daily. He remains well six months after diagnosis.

\section{Discussion}

These patients are similar to those with alpha chain disease previously described by Seligmann (Seligmann, Mihaesco, and Frangione, 1971). The age range of 17 to 36 , the clinical picture of abdominal pain, malabsorption, and clubbing, and the characteristic dense, predominantly plasma cell infiltrate of the small intestine, are associated with the presence of free alpha chain protein in serum, urine, and jejunal juice. The condition should, therefore, be suspected in any patient with malabsorption, a jejunal biopsy showing a diffuse plasma cell infiltration and an abnormal protein strip on electrophoresis. This paper adds a number of new findings to previous studies of alpha chain disease. These are: (1) an extension of the geographical incidence beyond the Mediterranean area; (2) spread of plasmacytosis beyond the intestinal tract, mesenteric nodes, and bone marrow; (3) the development of a new, simple diagnostic technique for the detection of free alpha chain protein; (4) response to intermittent cytotoxic therapy in three patients.

The series adds Bangladesh, Greece, Libya, Pakistan, and Persia to the now diverse geographical and ethnic origins of patients suffering from alpha chain disease. Whereas early reports of this disease were confined to patients with 'Mediterranean lymphoma' from the Middle East and North Africa (Rambaud et al, 1968; Rogé et al, 1970; Irrunberry et al, 1970) recently alpha chain disease has been described in Columbia, Argentina, Cambodia (Seligmann et al, 1971), Holland (Stoop, Ballieux, Hijmans, and Zegers, 1971), and probably in South Africa (Novis, Bank, Marks, Selzer, Kahn, and Sealy, 1971). In view of the wide geographical distribution and the apparent rarity of this condition in western countries, it has been suggested that intestinal
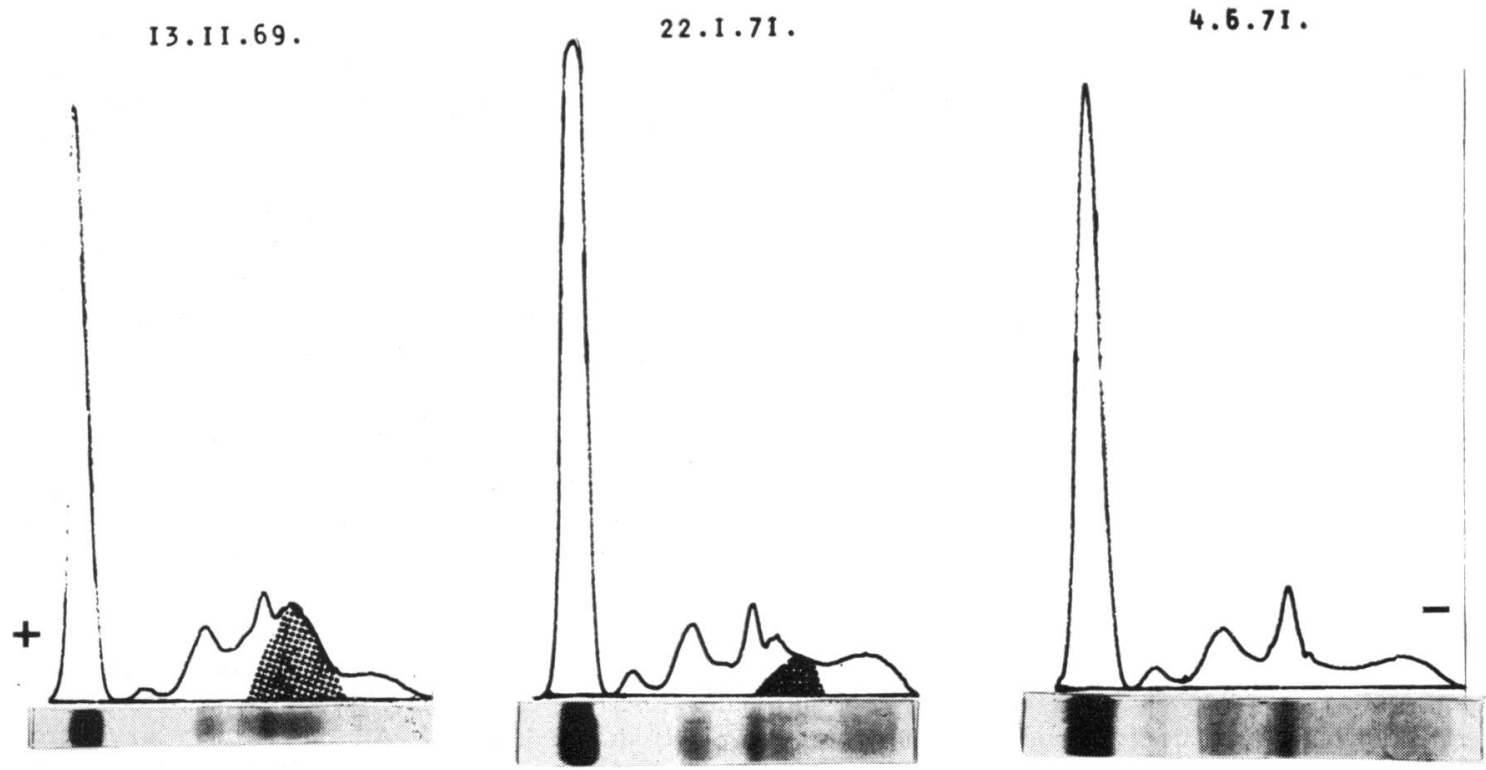

Fig. 8 Cellulose acetate electrophoresis of three successive sera from patient 3: before treatment (13.11.69), after treatment but relapsing due to lack of continued treatment (22.1.71), and finally after prolonged treatment with melphalan and prednisone (4.6.71) when little free $\alpha$-chain could be detected. 
infection, possibly parasitic, may be the common factor in these patients, providing a stimulus for excess proliferation of intestinal IgA synthesizing plasma cells (Seligmann et al, 1971).

A remarkable feature of all but one of the patients so far described with alpha chain disease is the initial confinement of the abnormal plasma cells to the wall of the small intestine. In the one exceptional case of alpha chain disease, only the lung appeared to be involved (Stoop et al, 1971).

Alpha chain disease differs quite clearly from soft tissue plasmacytomata. Of 228 patients with soft tissue plasmacytomata studied, 36 had involvement of the alimentary tract and in only eight of these was the tumour confined to the small intestine (Wiltshaw, 1969). Protein studies were carried out in a further series of soft tissue plasmacytomata. Of nine patients with gut plasmacytomata, eight had detectable paraproteins, five being IgG, two Bence Jones protein only, and one produced monoclonal 7S IgA. No secretory $\operatorname{IgA}$ was found in any of these tumours. IgA paraproteins were found in four soft tissue plasmacytomata not involving the gut. Both subclasses of IgA occurred and no free alpha chain was detected (Hobbs, 1972). Alpha chain disease thus uniquely arises in the intestinal or bronchial subepithelial tissue and so far only involves the alpha ${ }_{1}$ subclass of plasma cells.

The histological appearances of the jejunal mucosa showed a uniform abnormality in all five patients. Invasion of the submucosa was present in case 1 and possibly also in case 4 and evidence of spread beyond the intestine was obtained in cases 3 and 4 . In case 4, abnormal plasma cells appeared in the circulation, but these cells disappeared within two weeks of commencing cytotoxic therapy. The findings at ultrastructural level in case 5 clearly resembled those described in two cases of alpha chain disease (Scotto, Stralin, and Caroli, 1970). Case 3 differed, however, in that the plasma cells were more immature and in case 4 there were many cells of the intermediate lymphocytoid plasma cell type.

The immunoselection plate (Rádl, 1970) incorporating anti-K and anti- $\mathrm{L}$ light chains to precipitate all immunoglobulin molecules containing light chains, offers the clearest method of demonstrating the presence of free alpha chains or portions thereof. Such fragments were regularly found in the serum of these patients and also in jejunal fluid in cases 3 and 4 where the alpha chain was not associated with secretory piece. This finding conflicts with an earlier report by Seligmann, Mihaesco, Hurez, Mihaesco, Preud'homme, and Rambaud (1969) who found secretory piece associated with alpha chain in jejunal fluid.
In addition, free alpha chain protein was found in concentrated urine in cases 3,4 , and 5 , and jejunal biopsy culture fluid in case 3 . The alpha chains in all patients belonged to the alpha ${ }_{1}$ subclass identical to the first patient (T.L.) described with alpha chain disease (Rambaud et al, 1968) and all subsequent patients known (Seligmann et al, 1971). All five patients showed low serum levels of IgG and IgM. While the former could in part be due to increased catabolism consequent on protein-losing enteropathy, the levels of IgM were far lower than is usual from this cause alone (Waldmann, Gordon, Dutcher, and Wertlake, 1962).

Fluorescent studies frequently revealed that the abnormal plasma cells contained no light chains and less than the expected quantities of heavy chains. This could result from rapid excretion of newly synthesised alpha chain, but in cases 3 and 4 the endoplasmic reticulum appeared to be bulging with protein. This could support the hypothesis of intracellular proteolysis of alpha chains proposed by Seligmann et al (1971).

The level of free alpha chain in the sera and secretions of patients cannot be accurately measured by current methods. Our own study shows that it is valueless to measure IgA levels by radial immunodiffusion in these patients and in view of the variable degree of polymerization this method cannot be used to follow progress. On electrophoresis the zone is too diffuse and overlies other proteins so that area measurements are invalidated. Thus only a rough guide to treatment can be obtained by inspecting the cellulose acetate scans, although when alpha chain can no longer be detected by the immunoselection plate it has probably fallen below $30 \mathrm{mg}$ / $100 \mathrm{ml}$.

Intermittent cytotoxic therapy using Melphalan or cyclophosphamide with intermittent steroid therapy produced remissions in the three patients treated. Tetracyline was added to the regime in case 5 following recent reports of a remission achieved in a patient with alpha chain disease who was treated with long-term, broad-spectrum antibiotics alone (Rogé et al, 1970). The longest followup period in this series is three years. This patient (case 3) remains well with no detectable alpha chain protein in serum and with a greatly improved, though still abnormal, jejunal biopsy.

The authors wish to thank Dr Newcomb of Hackney for referring case 3, Dr Manousos of Athens who referred case 4, and Dr Ala of Tehran who referred case 5. We are grateful to Dr P. J. L. Holt for the tissue culture studies, and to Dr Slavin and Miss Marjorie Hoare for assistance with the protein studies. Tissue sections of cases 1 and 2 were kindly 
provided by Dr R. A. B. Drury of Central Middlesex Hospital and Professor R. Smith of University College Hospital. Case 2 has been previously reported as a case of steatorrhoea with striking increase of plasma alkaline phosphatase of intestinal origin (Dent, Norris, Smith, Sutton, and Temperley, 1968).

\section{References}

Ballard, H. S., Hamilton, L. M., Marcus, A. J., and Illes, C. H. (1970). A new variant of heavy-chain disease ( $\mu$ chain disease). New Engl. J. Med., 282, 1060-1062.

Dent, C. E., Norris, T. St. M., Smith, R., Sutton, R. A. L., and Temperley, J. M. (1968). Steatorrhoea with striking increase of plasma-alkaline-phosphatase of intestinal origin. Lancet, 1 , 1333-1336.

Doe, W. F., Hobbs, J. R., Henry, K., and Dowling, R. H. (1970). Alpha chain disease. Quart. J. Med., 39, 619-620.

Doe, W. F., Thomas, D., and Moss, D. W. (1972). In preparation.

Doniach, I., and Pelc, S. R. (1950). Autoradiograph technique. Brit. J. Radiol., 23, 184-192.

Franklin, E. C., Lowenstein, J., Bigelow, B., and Meltzer, M. (1964). Heavy chain disease: a new disorder of serum $\gamma$-globulins. Report of the first case. Amer. J. Med., 37, 332-350.

Hobbs, J. R. (1970). Simplified radial immunodiffusion. Broadsheet 68, Association of Clinical Pathologists.

Hobbs, J. R. (1972). Unpublished.

Irunberry, J., Benallegue, A., Illoul, G., Timsit, G., Abbadi, M. Benabdallah, S., Boucekkine, T., Ould-Aoudia, J. P., and Colonna, P. (1970). Trois cas de maladie des chaines alpha observés en Algérie. Nouv. Rev. franc. Hémat., 10, 609-616.

Laroche, C., Seligmann, M., Merillon, H., Turpin, G., Marche, C., Cerf, M., Lemaigre, G., Forest, M., and Hurez, D. (1970). Nouvelle observation d'une maladie des chaînes lourdes alpha au cours d'un lymphome abdominal de type 'méditerranéen' avec tuberculose isolée des ganglions mésentériques et pelvispondylite. Presse méd., 78, 55-59.

Novis, B. H., Bank, S., Marks, I. N., Selzer, G., Kahn, L., and Sealy, R. (1971). Abdominal lymphoma presenting with malabsorption. Quart. J. Med., 40, 521-540.

Rádl, J. (1970). Light-chain typing of immunoglobulins in small samples of biological material. Immunology, 19, 137-149.

Rambaud, J. C., Bognel, C., Prost, A., Bernier, J. J., Le Quintrec, Y., Lambling, A., Danon, F., Hurez, D., and Seligmann, M. (1968). Clinico-pathological study of a patient with 'Mediterranean' type of abdominal lymphoma and a new type of IgA abnormality ('Alpha Chain Disease'). Digestion, 1, 321-336.

Rogé, J., Druet, P., and Marche, C. (1970). Lymphome méditerranéen avec maladie des chaînes alpha: triple rémission clinique, anatomique et immunologique. Path. et Biol., 18 , 851-858

Scotto, J., Stralin, H., and Caroli, J. (1970). Ultrastructural study of two cases of a-chain disease. Gut, 11, 782-788.

Seligmann, M., Mihaesco, E., Hurez, D., Mihaesco, C., Preud'Homme J. L., and Rambaud, J. C. (1969). Immunochemical studies in four cases of alpha chain disease. J. clin. Invest. 48, 2374-2389.

Seligmann, M., Mihaesco, E., and Frangione, B. (1971). Alpha chain disease. Ann. N.Y. Acad. Sci., 190, 487-500.

Stoop, J. W., Ballieux, R. E., Hijmans, W., and Zegers, B. J. M. (1971). Alpha chain disease with involvement of the respiratory tract in a Dutch child. Clin. exp. Immunol., 9, 625-635.

Waldmann, T. A., Gordon, R. S., Jr., Dutcher, T. F., and Wertlake, P. T. (1962). Syndromes of gastrointestinal protein loss. In Plasma Proteins and Gastrointestinal Tract in Health and Disease, edited by M. Schwartz and P. Vesin, pp. 156-160. Munksgaard, Copenhagen.

Wieme, R. J. (1965). Agar Gel Electrophoresis. Elsevier, Amsterdam. Wiltshaw, E. (1969). The natural history of extramedullary plasmocytoma and its relation to solitary myeloma of bone and myelomatosis. MD Thesis, University of Wales, Cardiff, p. 151

Zlotnick, A., and Levy, M. (1971). a Heavy chain disease: a varian of Mediterranean lymphoma. Arch. intern. Med., 128, 432-436. 